\title{
Taguchi and Quadratic via Chromogenic Design Methodology: A Better to Best Estimation Process (Tizanidine Hcl) Bulk/Pharmaceutical
}

\author{
Vikash Kumar ${ }^{1}$, Kamal Dua ${ }^{2}$, Sushila Rathee ${ }^{1}$ and Permender Rathee ${ }^{3 *}$ \\ ${ }^{1}$ P. D. Memorial College of Pharmacy, Sarai Aurangabad, Bahadurharh, India \\ ${ }^{2}$ Department of Pharma Technology, School of Pharmacy, International Medical University, Malaysia
}

${ }^{3}$ Quantum Solutions India, Rajiv Gandhi Technology Park, Chandigarh, India

\begin{abstract}
A finest quantitative responsive with reproducible best method was developed using designed array (Taguchi) and Quadratic design methodology (RSM) chromomeric spectrophotometric estimation of bulk as well as pharmaceutical (Tizanidine $\mathrm{HCl}$ ). Initially (Taguchi), orthogonal array design was applied to find significant variables as well as optimum (better) levels. By response surface (central composite; quadratic) methodology were used to ascertain optimum to optimized "Better to Best" and studied values of variables (independent significant; $X_{1}=P D A B=$ chromogenic reagent; $\mathrm{FeCl}_{3}=\mathrm{X}_{2}=$ ferric ion at optimum levels with drug constant $=\mathrm{X}_{3}$ ) responses (dependent $Y_{1}=$ absorbance) models at positive and negative (+1/-1 optimum spaces) levels. More-more, designed independent factorial levels "better to best" surface models (3D) and its polynomial (2nd order) equation was predicted the finest level which further can be considered as best chromomeric estimation method. The models analysis of experimental variables and their level showed and followed good Beer's $(5-50 \mu \mathrm{g} / \mathrm{ml})$ correlation at optimized significant independent best (finest) level variables and in-addition validated using pharmaceutical guidelines $(\mathrm{ICH}$; international conference on harmonization) for human use.
\end{abstract}

Keywords: Statistical; Orthogonal array; Quadratic design; $3^{\mathrm{D}}$ Model; Analysis; Validation

\section{Introduction}

An carbocyclic hydrochloride derivative of Tizanidine (muscle relaxant; 5-Chloro-N-4,5-dihydro-1H-imidazol-2-yl-2,1,3benzothiadiazol-4-amine i.e.) which inhibited spinal reflex transmission via supra-spinal effects as a agonist ( $\alpha_{2}$ adrenergic). Also, having analgesic (pain relief) effects but non-steroidal anti-inflammatory drugs have also as one another effect i.e. gastro-protective. During literature, alicyclic amines (pyrrole/indole) condensed with p-dimethyl-aminobenzaldehyde (PDAB in strongly acidic medium and oxidized by ferric ions to give colored species/products including Schiff bases) derivatives as chromogenic agent alone via factorial designs were used for estimation/determination [1-3]. Although, there is no method was used non-factorial (quadratic design) with chromogenic or without. So, our research objective was developed plus validated a sensitive method using array Taguchi and quadratic (factorial independent; central composite) response surface design via chromomeric attempt for best estimation spectrophotometer methodology [4-7]. All experimental (orthogonal array) results of array (orthogonal) trials responses were interpreted to find significant variables and optimum levels (chromomeric reagents and ferric ion additional with different temperature, $\mathrm{pH}$, and time for reaction stability. More-over, an independent (quadratic) factorial design of significant variables with optimum (positive and negative space level) was performed and further studied their interactive effects. To designed better to Best level (nondependent); three-dimensional surface $\left(3^{\mathrm{D}}\right.$ plots) models constructed to preeminent (and also validated) fitted level of variables which can be considered as "Best level" for quantitative (Tizanidine $\mathrm{HCl}$ ) estimation.

\section{Materials and Methods}

The procured chemicals and reagents were (Lobachemicals Ltd. and S. D. Finechem Ltd, Mumbai) p-dimethyl-aminobenzaldehyde chromogenic (PDAB), Ferric ions (Ferric Chloride) and acid ( $\mathrm{HCl})$. For study, independent variables $\left(\mathrm{X}_{1}, \mathrm{X}_{2}\right.$, and $\left.\mathrm{X}_{3}\right)$ analytical (A/GR
200 Precision, Anakek Services, Mumbai) weight has been taken and made required concentrated solutions using distilled water of abode production. The standard of active pharmaceutical ingredients (drug; Tizanidine $\mathrm{HCl}$ ) derivative, Tizan and Sirdalud (2.288 mg; both) was obtained from M/S Jackson Pharmaceuticals Pvt. Ltd., Amritsar (Punjab) and market drug formulation from Sun Pharma and Novartis (Mumbai) respectively as gift sample. The hydrogen ion concentration ( $\mathrm{pH}$ meter; Aminco, Swastika, Ambala) and UV-Visible Double- Beam [spectral bandwidth $(1.8 \mathrm{~nm})$ with wavelength accuracy $(2 \mathrm{~nm})$ and optical path of quartz cells length (10 mm) (SL 160, Elico, Hyderabad) spectrophotometer at fixed wavelength was used through-out for analytical analysis as quantitative as absorbance measurement.

\section{Solutions}

The obtained gift sample (Tizanidine $\mathrm{HCl} ; 10 \mathrm{mg}$ ) was taken and dissolved in distilled water to acquired $(100 \mu \mathrm{g} / \mathrm{ml})$ desired concentration., chromomeric (PDAB; $1 \% \mathrm{w} / \mathrm{v})$ solution was prepared and diluted by using hydrochloric ( $50 \% \mathrm{v} / \mathrm{v})$ and aqueous ferric ion $(1 \%$ $\mathrm{v} / \mathrm{v}$; ferric chloride) solution and further used analytical determination as quantitative.

\section{Methodology}

A statistical (Mini-Tab, version 17.0) quadratic response

*Corresponding author: Permender Rathee, Quantum Solutions India Rajiv Gandhi Technology Park, Chandigarh, Tel: 0172221757 India, E-mail ratheepermender@gmail.com

Received September 17, 2014; Accepted November 10, 2014; Published November 17, 2014

Citation: Kumar V, Dua K, Rathee S, Rathee P (2014) Taguchi and Quadratic via Chromogenic Design Methodology: A Better to Best Estimation Process (Tizanidine Hcl) Bulk/Pharmaceutical. Pharm Anal Acta 5: 319. doi:10.4172/21532435.1000319

Copyright: ( 2014 Kumar V, et al. This is an open-access article distributed under the terms of the Creative Commons Attribution License, which permits unrestricted use, distribution, and reproduction in any medium, provided the original author and source are credited. 
Citation: Kumar V, Dua K, Rathee S, Rathee P (2014) Taguchi and Quadratic via Chromogenic Design Methodology: A Better to Best Estimation Process (Tizanidine Hcl) Bulk/Pharmaceutical. Pharm Anal Acta 5: 319. doi:10.4172/2153-2435.1000319

surface $[7,8]$ non-factorial methodology was used for design independent variables and spaces (levels). The diverse generated trials (experimentally T-1 to 20; Table 1) levels were additional diluted with distilled water for made the volumetric $(25 \mathrm{ml})$ finally. After that finally obtained volumes $(25 \mathrm{ml})$ of significant variables (A and B) solutions were heated at different temperatures $\left(40-80^{\circ} \mathrm{C}\right), \mathrm{pH}$ ( 1 to 6$)$ and time ( 5 to $60 \mathrm{~min}$ ) and measured the absorbance against blank $\left(\lambda_{\max } 425 \mathrm{~nm}\right.$; Figure 1). Before performed experimentally, again generated (BB1 to 13; Table 2) runs but using significant level of variables at positive and negative optimum space ( +1 to -1 ; better to best) level and analyzed their responses (experimental vs predicted; Table 2) model fitness to find out the variables level as best.

\section{Model and analysis}

The orthogonal array was used to find out optimum (better) level of significant variables which further used as independent (quadratic design i.e. response surface methodology explored and developed) level for an improved program). By data (Absorbance=R1) analyzed at optimum (better) to find optimized (best) levels were simultaneously. Also, illustrated designed surface $\left(3^{\mathrm{D}}\right)$ models and independently factorial generated equation were included all statistically coefficients of each level responses (Table 2) for "better to best" model fitness as best-fitted.

\section{Calibration curve}

The solutions ( $2 \mathrm{ml}$; Tizanidine hydrochloride) were pipette out and added chromogenic [PDAB $(4 \mathrm{ml})$ followed by ferric ion solution $(6 \mathrm{ml})$ as significant; $10 \mathrm{ml})]$ agent and further diluted to made optimized (best; $5-50 \mu \mathrm{g} / \mathrm{ml}$ ) concentration with distilled water. The resulted of significant variables solutions were sonicated $(15 \mathrm{~min})$ subsequently heated at optimum temperature $\left(60-65^{\circ} \mathrm{C}\right)$ at time $(20$ minutes) and measured the absorbance (at $425 \mathrm{~nm}$; pH 2) against the blank. The calibration curve was constructed by plotted the graph between absorbance and concentration (absorbance vs $\mu \mathrm{g} / \mathrm{ml}$ ) and showed better linearity with well coefficient of correlation (Figures 2 and 3).

\begin{tabular}{|c|c|c|c|}
\hline \multirow[t]{2}{*}{ Design Trials } & \multicolumn{2}{|c|}{ Levels (ml) } & \multirow{2}{*}{$\begin{array}{l}\text { Absorbance } \\
\text { At } \lambda_{\max } 425 \mathrm{~nm}\end{array}$} \\
\hline & PDAB reagent & Ferric Chloride & \\
\hline $\mathrm{T}-1$ & 1 & 1 & 0.233 \\
\hline $\mathrm{T}-2$ & 2 & 2 & 0.252 \\
\hline $\mathrm{T}-3$ & 3 & 3 & 0.276 \\
\hline $\mathrm{T}-4$ & 1 & 4 & 0.291 \\
\hline T-5 & 2 & 1 & 0.312 \\
\hline T-6 & 3 & 2 & 0.326 \\
\hline $\mathrm{T}-7$ & 4 & 3 & 0.335 \\
\hline $\mathrm{T}-8$ & 5 & 4 & 0.348 \\
\hline T-9 & 6 & 5 & $0.352^{*}$ \\
\hline $\mathrm{T}-10$ & 4 & 6 & $0.355^{*}$ \\
\hline $\mathrm{T}-11$ & 5 & 7 & $0.356^{*}$ \\
\hline $\mathrm{T}-12$ & 6 & 8 & $0.349^{*}$ \\
\hline $\mathrm{T}-13$ & 7 & 5 & 0.347 \\
\hline $\mathrm{T}-14$ & 8 & 6 & 0.341 \\
\hline $\mathrm{T}-15$ & 9 & 7 & 0.338 \\
\hline$T-16$ & 7 & 8 & 0.331 \\
\hline $\mathrm{T}-17$ & 8 & 9 & 0.324 \\
\hline $\mathrm{T}-18$ & 9 & 10 & 0.320 \\
\hline T-19 & 10 & 9 & 0.317 \\
\hline $\mathrm{T}-20$ & 10 & 10 & 0.315 \\
\hline
\end{tabular}

Aristech $\left({ }^{*}\right)$ value indicated the significant variable (better) optimum level response Table 1: Generated Array Trials At Diverse Levels (1 To 10).

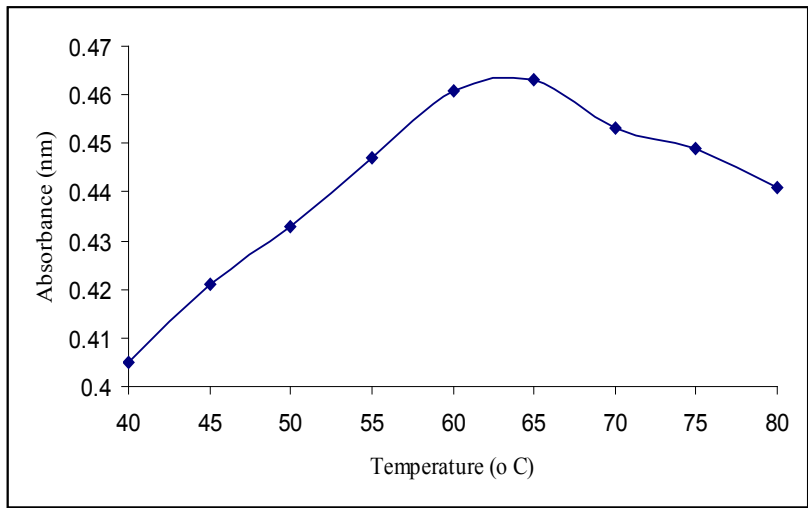

a)

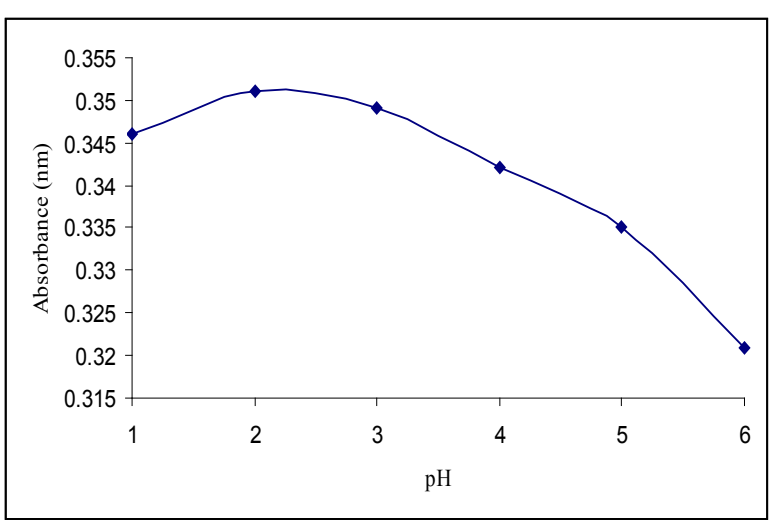

b)

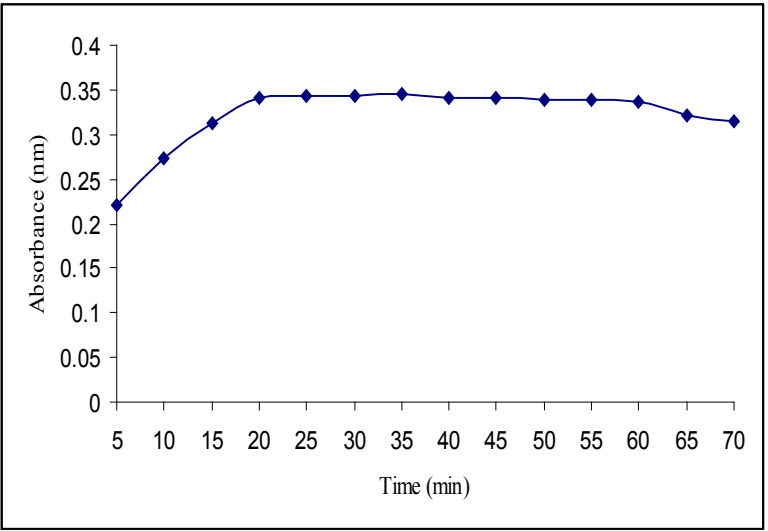

c)

Figure 1: Plots for optimization a) Temperature; b) $\mathrm{pH}$; c) $\mathrm{pH}$ d) reaction time for complex stability vs absorbance.

\section{Method of Estimation}

For the quantitative analysis, model drug derivative (tizanidine hydrochloride) in bulk and tablets [2.288 mg drug; Tizan (Sun-Pharma) and Sirdalud (Novartis)] were procured from the market, weighed (20 tablets of each brand) and powdered. The drug powdered was accurately weighed (10 mg equivalent for both the brands), transferred to flasks (volumetric; I and II) added distilled water ( $25 \mathrm{ml})$ then sonicated (15 min.) and finally distilled water was added to make-up the volume (up-to $100 \mathrm{ml}$ ) of both flask contained solution. The volumetric flask 
Citation: Kumar V, Dua K, Rathee S, Rathee P (2014) Taguchi and Quadratic via Chromogenic Design Methodology: A Better to Best Estimation Process (Tizanidine Hcl) Bulk/Pharmaceutical. Pharm Anal Acta 5: 319. doi:10.4172/2153-2435.1000319

Page 3 of 5

\begin{tabular}{|c|c|c|c|c|c|c|c|}
\hline \multirow{2}{*}{\multicolumn{2}{|c|}{$\begin{array}{l}\begin{array}{l}\text { Code=variables } \\
\text { (Unit) }\end{array} \\
X_{1}=\operatorname{PDAB}(\mathrm{ml}) \\
\end{array}$}} & \multicolumn{6}{|c|}{ "better to best" Independent (Space=Coded) Levels } \\
\hline & & \multicolumn{3}{|c|}{$4.00(-1=1)$} & \multicolumn{2}{|c|}{$5.00(0=2)$} & $6.00(+1=3)$ \\
\hline \multicolumn{2}{|c|}{$\mathrm{X}_{2}=\mathrm{FeCl}_{3}(\mathrm{ml})$} & \multicolumn{3}{|c|}{$5.00(-1=1)$} & \multicolumn{2}{|c|}{$6.00(0=2)$} & $7.00(+1=3)$ \\
\hline \multicolumn{2}{|c|}{ Dependant } & \multicolumn{6}{|c|}{ Constraints } \\
\hline \multicolumn{2}{|c|}{$Y_{1}=$ Absorbance } & \multicolumn{6}{|c|}{$0.56 \leq Y_{1} \geq 0.71$} \\
\hline \multicolumn{8}{|c|}{ Design Results } \\
\hline \multirow{3}{*}{\multicolumn{2}{|c|}{ Runs-Code }} & \multicolumn{6}{|c|}{ Variables } \\
\hline & & \multicolumn{3}{|c|}{ Independent } & \multicolumn{3}{|c|}{ Dependent $\left(\mathbf{Y}_{1}\right)$ Response $\left(R_{1}\right)$} \\
\hline & & \multicolumn{2}{|l|}{$\mathrm{X}_{1}$} & $\mathrm{X}_{2}$ & \multicolumn{2}{|l|}{ Observed } & Predicted \\
\hline \multicolumn{2}{|l|}{ BB-1 } & \multicolumn{2}{|l|}{1.00} & 1.00 & \multicolumn{2}{|l|}{0.665} & 0.670 \\
\hline \multicolumn{2}{|l|}{ BB-2 } & \multicolumn{2}{|l|}{2.00} & 1.00 & \multicolumn{2}{|l|}{0.571} & 0.570 \\
\hline \multicolumn{2}{|l|}{ BB-3 } & 3.00 & & 1.00 & 0.601 & & 0.600 \\
\hline BB-4 & & 1.00 & & 2.00 & 0.640 & & 0.640 \\
\hline BB-5 & & 1.00 & & 3.00 & 0.592 & & 0.590 \\
\hline BB-6 & & 2.00 & & 3.00 & 0.581 & & 0.580 \\
\hline BB-7 & & 3.00 & & 2.00 & 0.658 & & 0.660 \\
\hline BB-8 & & 2.00 & & 2.00 & 0.586 & & 0.590 \\
\hline BB-9 & & 2.00 & & 2.00 & 0.590 & & 0.590 \\
\hline BB-10 & & 2.00 & & 1.00 & 0.564 & & 0.570 \\
\hline BB-11 & & 2.00 & & 2.00 & 0.590 & & 0.590 \\
\hline BB-12 & & 2.00 & & 2.00 & 0.589 & & 0.590 \\
\hline BB-13 & & 3.00 & & 3.00 & 0.705 & & 0.700 \\
\hline Surface De & $\operatorname{sign}\left(3^{\circ}\right)$ & Best Mo & del & & & & \\
\hline Terms & Model & $x_{1}$ & $X_{2}$ & $x_{1} X_{2}$ & $\mathrm{X}_{1}^{2}$ & $\mathrm{X}_{2}{ }^{2}$ & Lack of Fit \\
\hline F value & 383.4 & 63.4 & 33.40 & 691.65 & 1061.8 & 37.20 & 1.70 \\
\hline Intercept & 0.59 & 0.011 & 0.0076 & 0.0445 & 0.064 & -0.012 & \\
\hline p. value (P & $o b>F)$ & 0.0001 & 0.0007 & $<0.0001$ & $1<0.0001$ & 0.0005 & 0.3040 \\
\hline R-Square & & Adjuste & $\mathrm{R}^{2}$ & Predicted & $d^{2} R^{2}$ & $\begin{array}{l}\text { Std. } \\
\text { Dev }\end{array}$ & $\% \mathrm{CV}$ \\
\hline 0.996 & & 0.994 & & 0.982 & & 0.0035 & 0.67 \\
\hline $\begin{array}{l}\text { F-value Les } \\
\text { Greater tha }\end{array}$ & $\begin{array}{l}s \text { than } 0 . \\
0.1000\end{array}$ & $\begin{array}{l}500 \text { indic } \\
\text { indicate } t\end{array}$ & $\begin{array}{l}\text { ate mode } \\
\text { he model }\end{array}$ & $\begin{array}{l}\text { el terms ar } \\
\text { terms are }\end{array}$ & $\begin{array}{l}\text { e significan } \\
\text { not signific }\end{array}$ & $\begin{array}{l}\text { t and La } \\
\text { cant }\end{array}$ & ack of fit value \\
\hline & Tabl & Resul & t Of Quac & dratic Desi & ign Method & ology. & \\
\hline Brand & & Amount & (mg) & & Percer & ntage \pm & SD \\
\hline & Lab & eled & Found & & Relative & & Labeled \\
\hline Tizan & & & 2.282 & & 0.0763 & 99.7 & $74 \pm 0.0761$ \\
\hline Sirdalud & & 88 & 2.281 & & 0.0989 & 99.7 & $73 \pm 0.0986$ \\
\hline
\end{tabular}<smiles>Clc1ccc2nsnc2c1NC1=NCCN1</smiles>

Tizanidine<smiles>[R]NC1=NCCN1</smiles><smiles>CN(C)C1CCC(C=O)CC1</smiles>

PDAB<smiles>CN(C)c1ccc(CO)cc1</smiles>

Charge Transfer Complex<smiles>[R]N([CH])C(O)c1ccc(N(C)C)cc1</smiles><smiles>[R][N+]([R])=Cc1ccc(N(C)C)cc1</smiles>

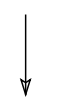<smiles>[R][N+]([R])C=C1C=CC(=[N+](C)C)C=C1</smiles>

Iminium Salt

Scheme 1: Better to Best (Level) Method.

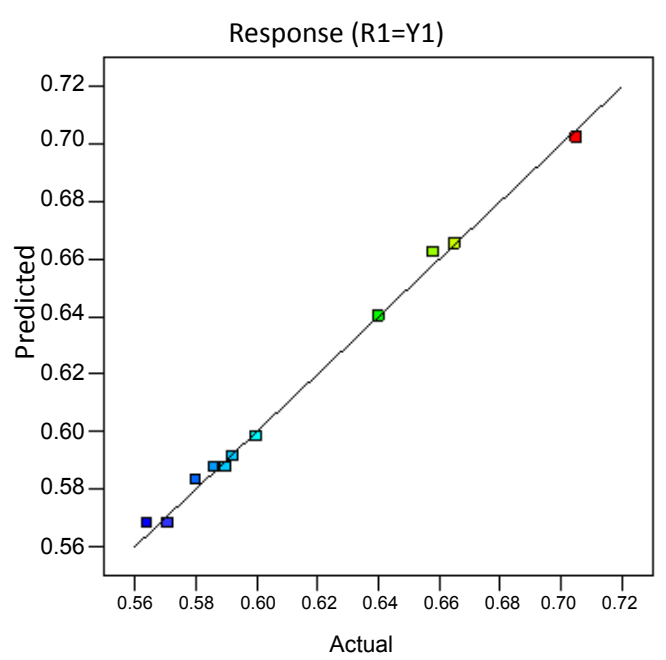

Figure 2: Linear correlation plots between actual and predicted values.

(I and II) solutions were filtered (Whatman filter paper no. 40). The sample solutions were prepared from [flask (I and II)] stock solution by appropriate dilutions and significant variable with optimized level to get desired concentrations with-in the Beer's law range limits and measured the absorbance against blank at $425 \mathrm{~nm}\left(\lambda_{\max }\right)$.

\section{Recovery and validation}

At this study carried-out, using (API 1, 2 and $3 \mathrm{mg}$ of drug and tablet) powder containing the equivalent to $(10 \mathrm{mg}$ drug) weight. After that, the methodology found amount was calculated the recovery (\%) and intra/inter-day precision (\%) relative standard deviation $[9,10]$ analysis to be satisfactory or not.

\section{Result and Discussion}

The chromogenic agent (PDAB) was selected (followed by dissolved in acid in the presence of ferric chloride) due to reagent [3] promising for the successful estimation of drugs having fused heterocyclic ring (Tizanidine $\mathrm{HCl}$ structure having indole heterocyclic moiety) in acid medium (Scheme 1). 


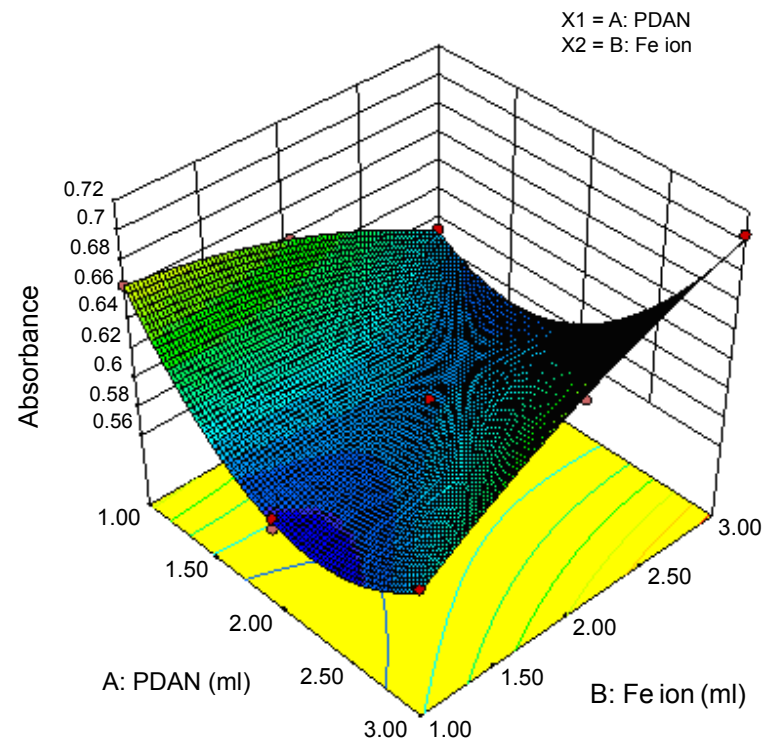

Figure 3: $3^{\mathrm{D}}$ surface models showed the levels (better to best) effect on response (Y1).

\section{Design and surface methodology}

A statistical program design (after found-out the variable significant and its optimum level; Table 1) independent methodology application without restrain of factorial/fractional factorial design was used. The significant variables optimum level optimized "better to best" (central composite) by surface design (RSM) and also, generated the equation of designed models and equation. Further, the optimized level of significant variables $(\mathrm{PDAB}=\mathrm{X} 1$; Ferric ion $=\mathrm{X} 2)$ fitted to best model with positive (1) and negative (-1) space value of response $(\mathrm{Y}$ experimental with predicted; Figure 2). Resulting, quadratic "better to best" design model optimized variables level was found (Table 2) for development of an optimized significant method of quantitative estimation/determination in bulk/pharmaceutical.

\section{Quadratic Equation}

A second-order polynomial derived equation of significant variables response $\left(\mathrm{R}_{1}\right)$ at optimized level was generated and the "better to best" model fitted proposed equation was as follows;

\section{$\mathrm{Y} 1=0.59+0.011 \mathrm{X} 1-0.0075 \mathrm{X} 2+0.0445 \mathrm{X} 1 \mathrm{X} 2+0.064 \mathrm{X}^{2}-0.012 \mathrm{X} 2^{2}$}

Where, $\mathrm{Y}_{1}$ is absorbance, $\mathrm{X}_{1}$ is PDAB-reagent, $\mathrm{X}_{2}$ is $\mathrm{FeCl}_{3}$.

The responses model proposed equation predicted R-square (0.982) found best fitted agreement with adjusted R-square (0.994; $\mathrm{R}$-square 0.996$)$ and measured a desirable signal to noise ratio ( $\mathrm{S} / \mathrm{N}>4$ desirable) by adequate precision (adequate 53.38). Due to best fitted model "F-value" (383.4; there is only $0.01 \%$ chance to occurred a large noise) implied that the model is significant ("Lack of Fit" F-value 1.70 is not significant). Therefore this model can be used to navigate the design space (surface $3^{-\mathrm{D}}$ plots) as optimized best independent levels of significant variables (Table 2) effects on response $\left(\mathrm{Y}_{1}\right) .3^{-\mathrm{D}}$ Analysis The dimensional models (optimized levels) response $\left(\mathrm{Y}_{1}\right)$ plots have been demonstrated the significant optimized variables at independently level interaction effects individually or along together at same time (Figure 3 ) on the response $\left(Y_{1}\right)$. The probability value (Table 2 ) of indicated the model optimized level significant terms $\left(\mathrm{X}_{1}, \mathrm{X}_{2} \mathrm{X}_{1} \mathrm{X}_{2,} \mathrm{X}_{1}{ }^{2}, \mathrm{X}_{2}^{2}\right)$ at negative space (level of $\mathrm{X}_{1}$ along with positive level space) had a more pronounced effect than any other optimum (better) levels. During model analysis, optimized "better to best" levels of variables $\left(\mathrm{X}_{1}\right.$ and $\left.\mathrm{X}_{2}\right)$ were negative $\left(-1=X_{1}=4 \mathrm{ml}\right.$ and $\left.5 \mathrm{ml}\right)$ and positive $\left(+1=X_{2}=6\right.$ or $\left.7 \mathrm{ml}\right)$ ferric ions space as comparison Also, an improved (good correlation coefficient) effects showed by response ( $\mathrm{R}_{1=}$ absorbance at optimized level), therefore this model design space can be used to investigate its surface $\left(3^{\mathrm{D}}\right.$ plots) which showed the independent effect of optimized levels of significant variables as on response $\left(\mathrm{Y}_{1}\right)$. Further-more, this model design of optimized of significant variables $\left(\mathrm{X}_{1}\right.$ and $\left.\mathrm{X}_{2}\right)$ levels independent effect can be used for "better to best" quantitative estimation method.

The significant variables best fitted levels $\left(\mathrm{X}_{1}=\mathrm{PDAB}=4 \mathrm{ml}\right.$ followed by ion solution $\mathrm{X}_{2}=\mathrm{FeCl}_{3}=6 \mathrm{ml}$ ) solutions into a volumetric flasks having drug solution (Tizanidine $\mathrm{HCl}=2 \mathrm{ml}$ ) were taken and finally made the volume with distilled water $(25 \mathrm{ml})$. Further, the solutions were heated at optimal temperature $\left(60-65^{\circ} \mathrm{C}\right.$ for time $20 \mathrm{~min}$ at $\left.\mathrm{pH} 2\right)$ for complete reaction and absorbance was measured against the blank at $425 \mathrm{~nm}$ wavelength (Table 3 ).

\section{Discussion and Conclusion}

The best designed method has better absorptivity $\left(4.717 \times 10^{3}\right.$ liter/ mole $/ \mathrm{cm}$ ) along with superior's sensitivity (Sand-ell' per absorbanceunits is $0.0615 \mu \mathrm{g} / \mathrm{cm}^{2} / 0.001$ ) and regression equation $[\mathrm{y}=0.0198 \mathrm{x}-$ 0.0673] showed better linearity with correlation coefficient (best fitted R-square value is 0.9964 ) as compared with existing method. During the intra (0.627) as well as inter-day (0.504) analysis has been found relative deviation (0.207) and quantitation (0.627) with-in limits and this higher recovery percentage indicated that there was no excipients interference. Further-more, indicated and concluded that the Taguchi array via Quadratic "independent" factorial designed chromomeric level (of better to best method) can be further considered as best for quantitative and quality reliable method of estimation.

\section{Acknowledgement}

The authors are thankful to Jackson Pharmaceutical Pvt. Ltd. (Amritsar) for providing model drug gift sample and grateful to Chairman/Management, PDMREA Group of Institution(s); P. D. Memorial College of Pharmacy, B'garh (India) India for facility and support.

\section{References}

1. Budavari S (1996) The Merck Index (12 ${ }^{\text {th }}$ Edn) Merck and Co., White House station, NJ.1618.

2. Rao KKV. Development and Validation of Spectrophotometric Methods for the Estimation of Tizanidine, Ind. Drugs; 2004, 583.

3. Rathee P, Dua K, Rathee S, Kumar V. Statistical design for optimization \& determination of Tizanidine $\mathrm{HCl}$ using folin-ciocalteu $(\mathrm{FC})$ as chromogenic reagent, Pharmaceutica Analytica Acta

4. Gurinder Singh, Roopa S Pai, V Kusum Devi (2012) Response surface methodology and process optimization of sustained release pellets using Taguchi orthogonal array design and central composite design. J Adv Pharm Tech Res 3: 30-40.

5. Singh G, Pai RS (2014) Optimization (central composite design) and validation of HPLC method for investigation of Emtricitabine loaded poly-(lactic-coglycolic acid) nanoparticles: In vitro drug release \& in vivo pharmacokinetic studies. The Sci World J.

6. Monaijemzadeh F, Hamishehkar H, Zakeri-Milani P, Farjami A, Valizadeh $\mathrm{H}$ (2013) Design and optimization of sustained-release Divalproex sodium tablets with response surface methodology. AAPS PharmSciTech 14: 245-253

7. Sonam Chaudhary H, Kumar V (2014) Taguchi design for optimization and development of antibacterial drug-loaded PLGA nanoparticles. Int $\mathrm{J}$ Bio Macromol 64: 99-105. 
Citation: Kumar V, Dua K, Rathee S, Rathee P (2014) Taguchi and Quadratic via Chromogenic Design Methodology: A Better to Best Estimation Process (Tizanidine Hcl) Bulk/Pharmaceutical. Pharm Anal Acta 5: 319. doi:10.4172/2153-2435.1000319

Page 5 of 5

8. Bolton S (1997) Pharmaceutical Statistics Practical and Clinical Application (3r Edn) New York: Marcel Dekker, Inc 265.
9. ICH, Tripartite harmonized Q2B guidelines. A text on validation of analytical procedures. 1996.

10. El Kousy NM (1998) Spectrophotometric and fluorimetric determination of Etodolac and Aceclofenac. J Pharm Biomed Anal 20: 185-194.
Citation: Kumar V, Dua K, Rathee S, Rathee P (2014) Taguchi and Quadratic via Chromogenic Design Methodology: A Better to Best Estimation Process (Tizanidine $\mathrm{Hcl}$ ) Bulk/Pharmaceutical. Pharm Anal Acta 5: 319 . doi:10.4172/2153-2435.1000319
Submit your next manuscript and get advantages of OMICS Group submissions

Unique features:

- User friendly/feasible website-translation of your paper to 50 world's leading languages

Audio Version of published paper

Digital articles to share and explore

Special features:

- 400 Open Access Journals

30,000 editorial team

21 days rapid review proces

Quality and quick editorial, review and publication processing

Indexing at PubMed (partial), Scopus, EBSCO, Index Copernicus and Google Scholar etc

- Sharing Option: Social Networking Enabled

- Authors, Reviewers and Editors rewarded with online Scientific Credits

- Better discount for your subsequent articles

Submit your manuscript at: http://www.editorialmanager.com/virology 